$\begin{array}{cccc}\text { S sciendo } & \text { International Conference KNOWLEDGE-BASED ORGANIZATION } \\ \text { Vol. XXV } & \text { No } 1 & 2019\end{array}$

\title{
CONSIDERATIONS ON SUSTAINABLE WATER RESOURCES MANAGEMENT
}

\author{
Elisabeta-Emilia HALMAGHI, Dănuț MOȘTEANU \\ "Nicolae Bălcescu" Land Forces Academy, Sibiu, Romania \\ emmahalmaghi@gmail.com,dmosteanu@gmail.com
}

\begin{abstract}
Water is essential to man's life, nature and economy and has a fundamental role in the climate regulation cycle. It is a resource that is continually regenerating, but is at the same time finite and cannot be produced or replaced by other resources. Nothing is possible without water, this resource being the heart of human and economic development. That is why water is an essential factor for the existence of life and the development of human society. Rapid urbanization, the global demographic explosion and climate change have led to water quality degradation and have become acute pressures on water resources, which has led to concern for water protection. Water is the common denominator that links all areas of activity, and these actions have the role of encouraging a better understanding of the need for water use and management in a more responsible manner.
\end{abstract}

\section{Keywords: water resources, sustainable management, water protection}

\section{Introduction}

Water is an indispensable factor for life, and it is essential for the life and health of human civilization, for industry and agriculture, but also for nature and climate regulation. Water plays a particularly important role in maintaining ecological balance and a healthy natural environment.

Although it is a resource that is continually regenerating, it is not infinite and cannot be produced or replaced by other resources.

Water resource management has arisen due to the shortage of water resources, the deterioration of its quality and the impact that floods have on the communities of people and the economy of the areas in which they occur.

\section{Research methodology}

The paper addresses the importance of sustainable water resource management as a result of limiting the use of water returned to nature due to the pollution of natural resources through the water used. The importance of water for the development of human civilization, the effects of population growth, economic development, agriculture and pollution of water resources, as well as the way in which a sustainable management of the resources of the population is presented and analyzed on the basis of consultation with the literature and direct observations. Water leads to avoiding and/or limiting the pollution of this resource of great importance to humans and the planet.

\section{The importance of water for humankind}

Water is at the origin of life on earth and is the main living environment. It plays a multilateral and complex role both in the lives of people and the activities they carry, as well as in the natural systems. The time and space distribution of water is particularly important because it represents the "engine" of life, being essential in all types of ecosystems existing on Earth and 
in providing water for the human population. The water covers about $71 \%$ of the Earth's surface. Approximately $2.5 \%$ of the water existing on Earth is freshwater and $98.8 \%$ of it is not available to humans, being in glaciers and underground waters. Available water for people's use comes from springs, running and standing waters, groundwater, rain and ice and snow melting. Underground reserves can be renewed through the water cycle in nature, but there are situations where, due to the intensive exploitation of aquatic resources, they cannot be renewed. It has long been assumed that there are enough water reserves and that they regenerate due to natural processes.

Figure no. 1 shows the distribution of water on Earth.

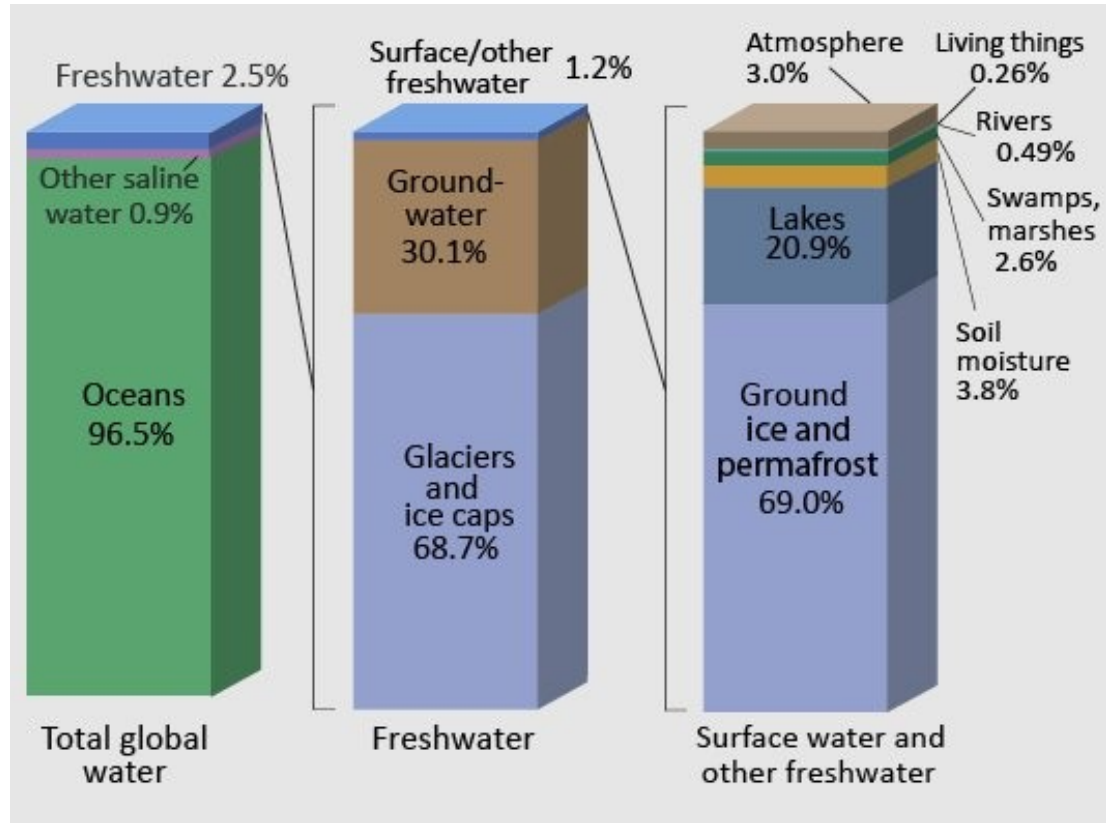

Figure 1: Water distribution on Earth

(Source: Alberto Montanari, Sustainable management of water resources, https://distart119.ing.unibo.it/albertonew/?q=node/128)

At present, freshwater resources in the world are under critical pressure due to the impact of the accelerated increase in the world's population, the development of economic activities in more and more areas of the world, the improvement of people's living conditions and the raising of the standard of living, conflicts and local wars. At the same time, social inequity, economic marginalization, lack of programs to reduce extreme poverty lead to competition for water resources, overexploitation of land and forestry resources, with negative impact on water resources.

Increasing the population of the world has also led to changes in the way in which mankind modifies watercourses or uses and pollutes water. Millions of peoplehave benefitedfrom building water sources for housing, industry and tourism, hydropower dams, irrigation systems for agriculture, waterways for freight and passenger transport, but they have also caused radical changes in the hydrological regime of ecosystems and the configurations of several river basins, lakes and aquifers. As water scarcity increases and hydrological variability increases, changes in hydro morphology of watercourses, as well as the continuous degradation of fresh water resources, lead to qualitative and quantitative water changes, affecting 
aquatic ecosystems.

Water pollution is closely related to human activity. Water collects and transports industrial, household and agricultural waste, which leads to its pollution. Impairment of water quality through pollution endangers the functioning of the aquatic ecosystem and people's health downstream from where the pollution occurred.

The use of water presents both positive and negative aspects. Some of the positive aspects of water use are:

a) supporting all human activities (agriculture, industry, tourism, fisheries, transport, electricity generation, etc.);

b) contributing to maintaining the health of people;

c) increasing the quality of life, etc.

The negative aspects of water use are:

a) carrying diseases (water-borne diseases currently cause between 2 and 5 million deaths annually);

b) flooding large areas;

c) prolonged drought can lead to people's deaths, losses in agriculture or the economic decline of the affected regions;

d) the lack of water leads to the occurrence or escalation of conflicts between communities living within local, national or cross-border river basins (when the basin is divided by several states of the world).

\section{Sustainable management of water resources - the key to the efficient use of water resources}

The problem of water resource decline and depletion affects both the population and the economy. There is increased pressure on water reserves due to: population growth, urban sprawl, rapid industrialization, intensive farming, growing areas in tourism, climate change. Pressure on water resources highlights existing economic, social, ecological and hydrological interdependencies, interdependencies that require integrated approaches to the development and management of water resources.
Sustainable management of water resources refers to the management of water and all aquatic resources in a way that is beneficial to both the environment and society by applying knowledge based on scientific results and local experience. This approach is much more comprehensive because it includes a wider range of objectives and possible activities, but also the improvement of institutional organization and working practices.

Sustainable management of water resources faces risks and pressures related to maintaining a balance between economic development, development and management of water resources so that water is not affected by pollution. The consequences of changes in flowing water flows, the reduction of groundwater surface, chemical and biological water pollution can be particularly severe. Rivers become overloaded with nutrients, leading to uncontrolled growth of aquatic vegetation. Degradation and destruction of ecosystems have negative effects on the lives of communities that depend on natural water resources. Polluted water leads to declining biodiversity, fishing regress, and people's illness in the community.

The main challenges faced by sustainable water resource management are:

a) poor management of water management the sector approach to water resource management leads to fragmented and uncoordinated water resource management and leads to inefficient management and increasing competition for scarce resources. b) providing water for the population - the first priority is to satisfy the fundamental water needs of the growing population.

c) water supply for food production currently more than $70 \%$ of the water is used in agriculture, and this quantity will increase in the future. Therefore, sustainable water resource management will need to find optimal solutions for managing water resources used in agriculture so as not to affect the water needs of the ever increasing population. 
d) the emergence of new jobs due to economic development - because all activities carried out by people are waterconsuming and waste-producing, when it is desired economic development of a region it is also recommended to take into account the water reserves existing in that region.

e) protection of vital ecosystems - in a hydro graphic basin the terrestrial and aquatic ecosystems bring a number of economic benefits due to the flora and fauna existing in the area. These ecosystems depend on water quality, seasonality, water flows and fluctuations in surface and groundwater levels. Upstream terrestrial ecosystems are important because they facilitate groundwater rehabilitation by filtering rainwater and maintain the flow rate of flowing water. Sustainable management of water resources and land in the vicinity of the water must ensure that ecosystems are kept as natural as possible and minimize the effects of human activity in those areas.

f) behavior with the variability of water in space and time - the greatest amount of water available for human use comes from precipitations that show high variations in space and time. This variability leads to the need to manage and control water supply and demand.

g) risk management - there are a number of factors that can lead to environmental, social and economic damage, damage to the health of the population, loss of life and destruction of ecosystem balance: water flow variations, long-term recovery of groundwater, drought and floods, water pollution. A particular place is the economic risk that may arise due to longterm investment requirements.

h) creating a public consciousness - for sustainable water management it is necessary to create public consciousness that will help to implement the necessary changes and to support actions for preventing and fighting water pollution.

i) politicians involvement in the sustainable management of water resources - political attention and commitment are essential in ensuring the most accurate decisions on the effective promotion of investments needed in the sustainable management of water resources.

j) collaboration between state institutions for the implementation of sustainable water resource management a very good collaboration between the state institutions is necessary in order to be able to plan, coordinate and implement the best management strategies.

\section{Conclusions}

Water is an essential resource for humans, animals and plants, and the increasing pressure on water reserves makes it necessary to apply sustainable water resources management.

Existing water resources have a significant impact on people, their health, agricultural production, economic development, and national security.

Proper management of existing water resources, whether we refer to surface or underground water, requires a sustainable management of water resources. Its implementation will ensure both the water resources needed for humanity in terms of changing rainfall variations and climatic changes, demographic growth, urbanization, economic development and food demand as well as limiting pollution and its negative effects on the ecosystem aquatic environment and areas in the vicinity of the waters.

\section{References}

[1] Gleick, Peter H. (editor), Water in Crisis. A Guide to the World's Fresh Water resources, Oxford University Press, 1993.

[2] Montanari, Alberto,Sustainable management of water resources, https://distart119.ing.unibo.it/albertonew/?q=node/128, accessed on 15.05.2019. 
[3] Seckler, David, Amarasinghe, Upali, Molden, David, Silva, Radhika de, Barker Randolph,World water demand and supply, 1990 to 2025: Scenarios and issues. Research Report 19, International Water Management Institute, Colombo, Sri Lanka, 1998.

[4] Managementul Integrat al Resurselor de Apă, Global Water Partnership, 2009, https:/www.gwp.org/globalassets/global/toolbox/publications/background-papers/04.integrated-water-resources-management-rumanian.pdf, accesed on 12.05.2019.

[5] Un Manual pentru Managementul Integrat al Resurselor de Apă în Bazinele Hidrografice, Global Water Partnership, 2009, https://www.riob.org/sites/default/files/Methodological_guidebook_IWRM-RO.pdf, accessed on 10.05.2019. 